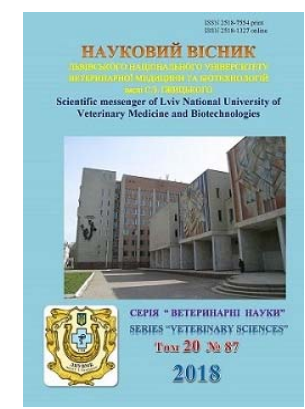

\author{
Науковий вісник Дьвівського національного університету \\ ветеринарної медицини та біотехнологій імені С.3. Гжицького
}

\author{
Scientific Messenger of Lviv National University \\ of Veterinary Medicine and Biotechnologies
}

\title{
To studying the development of technological stress in the organism of piglets during the influence of the feed additives «Praimiks Bionorm K»
}

\author{
V.G. Stoyanovskyy, O.I. Kamratska, I.A. Kolomiiets, O.I. Slepokura \\ Stepan Gzhytskyi National University of Veterinary Medicine and Biotechnologies Lviv, Ukraine
}

Article info

Received 26.01.2018

Received in revised form 01.03 .2018

Accepted 06.03.2018

Stepan Gzhytskyi National University of Veterinary Medicine and Biotechnologies Lviv, Pekarska str., 50, Lviv, 79010, Ukraine.

Tel.: +38-097-587-25-72. E-mail: okamracka@gmail.com
Stoyanovskyy, V.G., Kamratska, O.I., Kolomiiets, I.A.\& Slepokura, O.I. (2018). To studying the development of technological stress in the organism of piglets during the influence of the feed additives "Praimiks Bionorm K». Scientific Messenger of Lviv National University of Veterinary Medicine and Biotechnologies. 20(87), 8-12. doi: 10.15421/nvlvet8702

The article is devoted to increasing the preserving and survival of piglets in conditions of industrial cultivation, where their organism is exposed to constant effects of adverse technological factors. The state of stress that occurs in this case leads to a decrease in the rate of growth and resistance of the young to a variety of diseases and can ultimately cause death of animals. One of the most promising directions for preventing the negative effects of stress and increasing the overall resistance of the piglet organism is the search, development and introduction of dietary supplements that increase physiological processes in the body, improve metabolism, increase the energy of growth, increase the yield of meat products. The purpose of the work was to find out the physiological state of a piglet organism during the period of weaning at the influence of the biologically active feed supplement "Praimiks Bionorm K» in the conditions of the SEPC "Komarnivsky». The research was carried out on piglets of 5 - 60-day-old age of the Poltava beef breed. Technological stress was the weaning of piglets at 40 days of age and the group maintenance of them with a change in the structure of the ration during the growing season. Piglets of the experimental group, together with the main feed, were additionally fed with «Praimiks Bionorm K» in the amount of $9.0 \mathrm{~g} / 100 \mathrm{~kg}$ of feed (manufacturer - biotechnology company «Ariadna» Odessa). According to the results of the conducted research, it was found that the process of adaptation of the organism of the piglets of the control group to the stress isolation after 5 days was accompanied by an increase in blood hemoglobin concentration in 1.35 times $(P<0.01)$, the number of leukocytes - by 1.21 times $(P<0.05)$ at the expense of rodent and segmental neutrophils and monocytes -1.54 times $(P<0.01)$, with a decrease in the number of eosinophils -3.0 times $(P<0.001)$ and lymphocytes -1.15 times $(P<0.01)$, compared with the period before weaning. 20 days after weaning in the K group, there was a decrease in the number of eosinophils in the blood by 2.25 times in the blood and lymphocytes by 1.25 times $(P<0.01)$, in the increase in the cellular and segmental neutrophils by 2.15 and 1.90 times, monocytes - by 1.85 times $(P<0.01)$ in comparison with the period before weaning. Neutrophilia, lymphopenia and eosinopenia were the most pronounced and persistent signs of stress in the piglets of the $K$ group that arose out of the regulatory influence of glucocorticoids. While using biologically active feed supplement «Praimiks-Bionorm K» 5 days after weaning in the blood of piglets, the content of hemoglobin increased by 1.26 times; after 20 days its concentration increased by 1.22 times, as well as the increase in the number of leukocytes in 1.22 times $(P<0.01)$, neutrophils of rod-nuclei -2.0 times, segmental ones -1.37 times $(P<0.01)$, compared to control. The obtained results indicate that the use of BAFA «Praimiks Bionorm-K» allows to prevent the development of stressful events in the piglet organism, improve the status of the cellular level of nonspecific resistance and the level of productivity during the period of weaning and at different stages of development of the stress reaction after weaning.

Key words: red blood cells, leukocytes, leukogram, piglets, weaning, stress, adaptation, feed additive.

\section{До вивчення розвитку технологічного стресу в організмі поросят за впливу кормової добавки «Праймікс Біонорм К»}

\author{
В.Г. Стояновський, О.І. Камрацька, I.А. Коломієць, О.І. Слепокура
}

Львівський національний університет ветеринарної медицини та біотехнологій імені С.3. Гжиџького, 


\section{м. Львів, Україна}

Стаття присвячена підвищенню збереження та життєздатності поросят в умовах промислового вирощування, де їхній організм піддається постійній дї̈ несприятливих технологічних чинників. Стресовий стан, який при цььому виникає, призводить до зниження швидкості росту та стійкості організму молодняку до різноманітних хвороб і в кінцевому результаті може викликати загибель тварин. Одним з найбільш перспективних напрямів профілактики негативних наслідків стресу $і$ підвищення загальної резистентності організму поросят є пошук, розробка і впровадження у раціон кормових добавок, щзо посилюють фізіологічні прочеси в організмі, покрашують обмін речовин, підвищують енергію росту, збільшують вихід м'ясної продукиії. Метою роботи було з'ясувати фізіологічний стан організму поросят у період відлучення за впливу біологічно активної кормової добавки «Праймікс Біонорм К》 в умовах ННВЦ «Комарнівський». Дослідження проведено на поросятах 5 - 60-добового віку полтавської м ясної породи. Технологічним стресом було відлучення поросят у 40-добовому віці та групове їх утримання зі зміною структури раціону у період дорошування. Поросятам дослідної групи разом з основним кормом додатково згодовували «Праймікс Біонорм К» у кількості 9,0 г/100 кг корму (виробник - біотехнологічна компанія «Аріадна» м. Одеса). За результатами проведених досліджень встановлено, шчо процес адаптації організму поросят контрольної групи до стресу відлучення через 5 діб супроводжувався збільщенням у крові концентрації гемоглобіну в 1,35 раза $(P<0,01)$, кількості лейкочитів - в 1,21 раза $(P<0,05)$ за рахунок паличко- та сегментоядерних нейтрофілів і моноцитів - у 1,54 раза $(p<0,01)$, при зменшенні кількості еозинофілів - у 3,0 рази $(P<0,001)$ і лімфоцитів - в 1,15 раза $(P<0,01)$, порівняно з періодом до відлучення. Через 20 діб після відлучення у К групі тварин спостерігалося зменшення у крові кількості еозинофілів у 2,25 раза та лімфоцитів - в 1,25 раза (P<0,01), збільшення паличко- та сегментоядерних нейтрофілів у 2,15 і 1,90 раза, моночитів - в 1,85 раза (P < 0,01) порівняно з періодом до відлучення. Нейтрофілія, лімфопенія $i$ еозинопенія були найбільш вираженими і постійними ознаками стресу у поросят К групи, ияо виникали за регуляторного впливу глюкокортикоїдів. За використання біологічно активної кормової добавки «Праймікс-Біонорм К» через 5 діб після відлучення у крові поросят збільшувався вміст гемоглобіну в 1,26 раза, через 20 діб зростала його концентрація в 1,22 раза, а також збільшувалася кількість лейкочитів - в 1,22 раза (P<0,01), нейтрофілів паличкоядерних - у 2,0 рази, сегментоядерних - в 1,37 раза $(P<0,01)$ порівняно з контролем. Отримані результати вказують на те, шуо використання БАКД «Праймікс Біонорм-К» дозволяє попередити розвиток стресових явищ в організмі поросят, підвищити стан клітинної ланки неспецифічної резистентності у період відлучення та в різні стадї розвитку стресової реакиї після відлучення.

Ключові слова: еритроччти, лейкочити, лейкограма, поросята, відлучення, стрес, адаптачія, кормова добавка.

\section{Вступ}

Підвищення збереження та життєздатності поросят в умовах промислового вирощування відноситься до найбільш актуальних науково-практичних проблем сучасного свинарства (Chumachenko, 2004; Gutyj et al., 2017). Період відлучення поросят від свиноматок, зважування і переміщення молодняку, об'єднання їх у нові групи, зміна режиму годівлі та складу корму негативно впливають на фізіологічний стан організму молодняку тварин. Доведено, що будь-які зміни у складі раціону зумовлюють прояв адаптаційнокомпенсаторних реакцій ферментних систем кишкового мікробіоценозу, імунної системи кишечнику та органів травлення тварин (Stojanovskyj et al., 2016). Стресовий стан, який при цьому виникає, призводить до зниження швидкості росту та стійкості організму молодняку до різноманітних хвороб і в кінцевому результаті може викликати загибель тварин (Gleimer and Parham, 2003). Одним з найбільш перспективних напрямів профілактики негативних наслідків стресу, відновлення складу мікрофлори, запобігання іiі порушень, а також підвищення неспецифічної резистентності організму поросят $є$ інтегровані схеми застосування пробіотичних добавок, що посилюють фізіологічні процеси в організмі, покращують обмін речовин, підвищують енергію росту, збільшують вихід м'ясної продукції (Panin and Malik, 2006). Основними компонентами пробіотичних кормових добавок $є$ лакто-, біфідобактерії, що мають антагоністичну активність стосовно до широкого спектра патогенної і умовнопатогенної мікрофлори, здійснюють синтез вітамінів, амінокислот, ферментів, сприяють поліпшенню травлення і засвоєнню кормів, стимулюють імунну систему і підвищують стійкість організму тварин до інфекційних захворювань та інших несприятливих чинників (O'Mahony et al., 2009; Rider et al., 2017). Основою розробки науково обгрунтованої системи профілактики імунодефіцитів та кишкових захворювань у поросят є вивчення фізіологічних особливостей становлення механізмів адаптації їх організму за дії стресу.

Мета роботи - з'ясувати фізіологічний стан організму поросят у період відлучення за впливу біологічно активної кормової добавки (БАКД) «Праймікс Біонорм К» в умовах ННВЦ «Комарнівський».

\section{Матеріал і методи досліджень}

Усі маніпуляції з поросятами проводили 3 дотриманням вимог «Європейської конвенції про захист хребетних тварин, які використовуються для експериментальних і наукових цілей» (Страсбург, 1986), ухвали Першого національного конгресу 3 біоетики (Київ, 2001) - «Загальні етичні принципи експериментів на тваринах» та 3 дотриманням принципів гуманності, викладених у директиві Європейської Спільноти. Дослід проведено в умовах ННВЦ «Комарнівський» ЛНУВМБТ імені С.З. Гжицького на поросятах 560-добового віку полтавської м'ясної породи. Для досліджень було сформовано дві групи поросят контрольна (К) і дослідна (Д), по 10 голів у кожній. Годівля тварин проводилась відповідно до норм для даного віку свиней. Починаючи 3 25-добового віку поросят К групи підгодовували престартерним комбікормом, Д групі разом з основним кормом додатково згодовували БАКД «Праймікс Біонорм К» у кількості 9,0 г/100 кг корму (виробник - біотехнологічна компанія «Аріадна», м. Одеса).

Технологічним стресом було відлучення поросят у 40-добовому віці та групове їх утримання зі зміною структури раціону в період дорощування. Матеріалом для досліджень слугувала кров, яку отримували вранці, до годівлі тварин шляхом пункції краніальної порожнистої вени на 40 добу життя (до відлучення), 45 і 
60 добу життя (через п’ять і двадцять діб після відлучення, що відповідає стадії резистентності за Сельє) у кількості 5 особин в кожному стресовому періоді. У крові визначали: кількість еритроцитів, лейкоцитів за допомогою камери Горяєва, диференційний підрахунок лейкоцитів проводила під мікроскопом на пофарбованих за Романовським-Гімзою мазках крові; величину гематокриту - шляхом центрифугування на гематокритній центрифузі МЦГ-8; вміст гемоглобіну колориметрично - гемоглобін-ціанідним методом (Vlizlo et al., 2012). Статистичну обробку цифрових даних проводили за допомогою програми Statystika для Windows XP. Визначали ступінь вірогідності різниці (Р) між досліджуваними показниками поросят К і Д групи. Результати середніх значень вважали статистично вірогідними при $\mathrm{P}<0,05-*, \mathrm{P}<0,01-* *$, $\mathrm{P}<0,001-* * *$.

\section{Результати та їх обговорення}

Результати дослідження морфологічних показників крові поросят за дії стресу при згодовуванні БАКД «Праймікс Біонорм К» наведені у таблиці 1. Дослідження кількості еритроцитів і лейкоцитів у крові поросят 40-добового віку показали, що величина цього показника перебувала в межах фізіологічних величин, характерної для даної вікової групи тварин, тимчасом як у Д групі величини цих показників були вищими відповідно на 1,99 і 16,71\%. Експериментально встановлено, що вміст гемоглобіну в еритроцитах поросят 40-добового віку К групи становив $87,62 \pm 2,50$ г/л, а Д групі підвищувався до $107,88 \pm 5,80$ г/л $(\mathrm{P}<0,05)$, що було ознакою посилення окисно-відновних процесів в організмі тварин. При аналізі гематокритної величини як ключового показника гемопоетичної функції організму було встановлено, що на 40 добу життя в поросят К групи вона складала $33,2 \pm 1,93 \%$, а у поросят Д групи, до складу раціону яких вводили «Праймікс Біонорм К», була вірогідно вищою на 16,26\% (Р < 0,05), що вказувало на інтенсивні процеси кровотворення в їхньому організмі.

Як відомо, розвиток стресу супроводжується напруженням окремих органів і систем організму, змінами його гормонального фону, інтенсивністю метаболізму та активністю фізіологічних функцій (Frick et al., 2009; Nallagatla et al., 2011). Аналізуючи результати дослідження кількості еритроцитів у крові поросят 45-добового віку (початок стадії резистентн,ості) варто звернути увагу на те, що у групі їх числове значення підвищувалося на 7,52\%, порівняно 3 періодом перед відлученням, тимчасом як у поросят Д групи величина цього показника зросла на 16,27\%. Варто відзначити, що у крові поросят, що отримували БАКД «Праймікс Біонорм К» кількість еритроцитів була вищою на 10,29\% порівняно з К групою тварин.

\section{Таблиця 1}

Морфологічні показники крові поросят за дії стресу відлучення при згодовуванні БАКД «Праймікс Біонорм К», $(\mathrm{M} \pm \mathrm{m}, \mathrm{n}=5)$

\begin{tabular}{|c|c|c|c|}
\hline \multirow{2}{*}{ Групи } & \multicolumn{3}{|c|}{ Вік поросят, діб } \\
\hline & 40 & 45 & 60 \\
\hline \multicolumn{4}{|c|}{ Кількість еритроцитів, Т/л } \\
\hline K & $4,52 \pm 0,24$ & $4,86 \pm 0,12$ & $4,91 \pm 0,10$ \\
\hline Д & $4,61 \pm 0,25$ & $5,36 \pm 0,20$ & $5,00 \pm 0,51$ \\
\hline \multicolumn{4}{|c|}{ Кількість лейкоцитів, Г/л } \\
\hline K & $8,38 \pm 0,44$ & $10,10 \pm 0,82$ & $9,66 \pm 0,54$ \\
\hline Д & $9,78 \pm 0,57$ & $10,66 \pm 0,51$ & $11,98 \pm 0,34 * *$ \\
\hline \multicolumn{4}{|c|}{ Концентрація гемоглобіну, г/л } \\
\hline K & $87,62 \pm 2,50$ & $118,88 \pm 2,72$ & $116,52 \pm 6,10$ \\
\hline Д & $107,88 \pm 5,80 *$ & $135,60 \pm 5,27^{*}$ & $131,10 \pm 7,83$ \\
\hline \multicolumn{4}{|c|}{ Величина гематокриту, \% } \\
\hline K & $33,24 \pm 1,93$ & $35,20 \pm 1,36$ & $35,40 \pm 1,47$ \\
\hline Д & $38,60 \pm 1,03^{*}$ & $37,60 \pm 0,75$ & $37,00 \pm 1,41$ \\
\hline
\end{tabular}

3 результатів, наведених у таблиці 1, бачимо, що після відлучення від свиноматки відзначали тенденцію до зростання кількості лейкоцитів. Зокрема, було 3'ясовано, що в 45-добовому віці у поросят К групи їх кількість збільшилася на 20,52\% (P < 0,05), а у поросят Д групи на 8,99\% порівняно з попереднім досліджуваним періодом без вірогідних різниць між К і Д групами тварин. Відомо, що підвищена концентрація гормонів надниркових залоз у плазмі крові тварин $€$ фізіологічною реакцією на дію екзогенних стресорів, які призводять до підвищення рівня кортикостероїдів, викликає зміни морфологічного складу крові, збільшення загальної кількості формених елементів. Після відлучення від свиноматки відзначали вірогідно вищу концентрацію гемоглобіну в крові поросят К і Д гру- пи, порівняно з 40-добовими тваринами. По відношенню до К групи вміст гемоглобіну у крові поросят, що отримували БАКД «Праймікс Біонорм К», був вищим на $14,06 \%$ ( $<0,05)$. Результати досліджень показали, що у поросят К групи величина гематокриту зростала до $35,20 \pm 1,36 \%$ або на $6,02 \%$, що можна пов'язувати із зростанням кількості еритроцитів у цей період, посиленням синтезу еритропоетину як наслідок адаптації організму до зміни типу годівлі. У поросят Д групи рівень гематокриту був стабільно вищим і становив $37,60 \pm 0,75 \%$, що зумовлено однією з функцій біфідобактерій, що входять до складу добавки, а саме: синтез вітамінів групи $\mathrm{B}\left(\mathrm{B}_{1}, \mathrm{~B}_{2}, \mathrm{~B}_{3}, \mathrm{~B}_{6}, \mathrm{~B}_{12}\right)$, які беруть безпосередню участь у процесах еритропоезу (Kogelberg and Feizi, 2001). 
При дослідженні морфологічних показників крові поросят К і Д групи на більш пізніх етапах стадії резистентності виявлено підвищення кількості еритроцитів до 4,91 $\pm 0,10$ Т/л. Порівняно 3 тваринами К групи величина досліджуваного показника у поросят, що отримували БАКД «Праймікс Біонорм К» була вищою на 1,83\%. В цей період встановлені характерні зміни у кількості лейкоцитів, коли у крові К групи тварин їх число знижувалося до величини вихідного вікового періоду, а у Д групі було вірогідно вищим не тільки порівняно з попередніми віковими періодами, а й порівняно з К групою тварин на $24,02 \%(\mathrm{P}<0,01)$. Вірогідне зростання кількості лейкоцитів у Д групі могло бути обумовлене одними з основних властивостей мікроорганізмів, що входять до складу добавки: забезпечення колонізаційної резистентності, конкурентного виключення умовно патогенної мікрофлори та імуностимулюючою функцією нормофлори кишечнику, що слугує джерелом ад’ювантноактивних речовин для імунокомпетентної системи організму. На 60 добу життя поросят концентрація гемоглобіну перебувала в межах величини цього показника у тварин 45добового віку, що більше пов'язано з віковою динамікою вмісту гемоглобіну в еритроцитах поросят. Отримані числові значення кількості еритроцитів i лейкоцитів, концентрації гемоглобіну в крові поросят усіх груп в нашому випадку зростала з 40 до 60 доби життя, що можна пов'язувати 3 розвитком захиснокомпенсаторних реакцій для запобігання порушення гомеостазу в період відлучення та зміни раціону. Порівняно 3 тваринами К групи, вміст гемоглобіну в крові поросят Д групи на 60 добу життя був на 12,51\% вищим, залишаючись у межах вірогідних коливань. Гематокритна величина крові поросят К і Д групи у 60-добовому віці була аналогічною такій у 45добових тварин, а його висока інформативність для характеристики гемопоезу обумовлена точним визначенням об'ємної частки клітинного комплексу формених елементів крові. Величина гематокриту крові поросят К і Д групи характеризувала трофічний i функціональний стан організму, умови гемоциркуляції, ефективність дихальної функції та клітинної бази імунної системи.

Аналіз лейкограми має важливе значення у клінічній практиці, оскільки при будь-яких функціональних станах організму тварин відсотковий вміст окремих елементів білої крові зменшується або збільшується за рахунок змін інших (Snodgrass et al., 2016). Велике значення має оцінювання лейкограми периферичної крові тварин при порушеннях метаболізму та регуляторних функцій в організмі за дії стресових факторів. При аналізі лейкограми крові поросят (табл. 2) встановлено, що на 40 добу життя простежувалося зростання кількості еозинофілів, нейтрофілів та моноцитів у крові тварин Д групи, тимчасом як кількість лімфоцитів перебувала у межах величини цього показника поросят К групи. Через 5 діб після відлучення у крові тварин К групи відмічено вірогідне зниження втричі кількості еозинофілів ( $<<0,001)$ та в 1,2 рази лімфоцитів ( $\mathrm{P}<0,01)$, збільшення в 1,8 та 1,7 раза $(\mathrm{P}<0,01)$ кількості паличко- та сегментоядерних нейтрофілів ( $\mathrm{P}<0,01)$, в 1,5 рази моноцитів $(\mathrm{P}<0,01)$, порівняно 3 таким періодом до відлучення.

\section{Таблиця 2}

Лейкограма крові поросят за дії стресу відлучення при згодовуванні БАКД «Праймікс Біонорм К» (\%), (M \pm m, $\mathrm{n}=5$ )

\begin{tabular}{|c|c|c|c|c|c|c|}
\hline \multirow{2}{*}{$\begin{array}{l}\text { Групи } \\
\text { тварин }\end{array}$} & \multirow[b]{2}{*}{ Базофіли } & \multirow[b]{2}{*}{ Еозинофіли } & \multicolumn{2}{|c|}{ Нейтрофіли } & \multirow[b]{2}{*}{ Лімфоцити } & \multirow[b]{2}{*}{ Моноцити } \\
\hline & & & Паличкоядерні & $\begin{array}{c}\text { Сегменто } \\
\text { ядерні }\end{array}$ & & \\
\hline \multicolumn{7}{|c|}{40 діб } \\
\hline $\mathrm{K}$ & - & $5,4 \pm 0,24$ & $2,0 \pm 0,32$ & $14,8 \pm 0,58$ & $75,2 \pm 2,38$ & $2,6 \pm 0,24$ \\
\hline Д & - & $4,2 \pm 0,86$ & $2,9 \pm 0,32$ & $20,1 \pm 1,71$ & $69,6 \pm 1,03$ & $3,2 \pm 0,58$ \\
\hline \multicolumn{7}{|c|}{45 діб } \\
\hline $\mathrm{K}$ & - & $1,8 \pm 0,37$ & $3,6 \pm 0,4$ & $25,4 \pm 2,37$ & $65,2 \pm 0,86$ & $4,0 \pm 0,32$ \\
\hline Д & - & $3,3 \pm 0,59$ & $3,2 \pm 1,7$ & $30,4 \pm 3,33^{* *}$ & $59,1 \pm 1,83 * *$ & $4,0 \pm 0,32$ \\
\hline \multicolumn{7}{|c|}{60 діб } \\
\hline K & - & $2,4 \pm 0,51$ & $4,3 \pm 0,51$ & $28,6 \pm 2,01$ & $59,8 \pm 1,85$ & $4,8 \pm 0,37$ \\
\hline Д & - & $3,9 \pm 0,75$ & $5,8 \pm 1,36$ & $27,6 \pm 3,59$ & $58,6 \pm 2,32$ & $4,1 \pm 0,37$ \\
\hline
\end{tabular}

Нейтрофілію в період стресу внаслідок збільшення вмісту кортикостероїдів в циркулюючій крові обумовлює прискорене вивільнення гранулоцитів кістковим мозком, зниження виходу поліморфноядерних клітин в тканинах, відповідно збільшення пулу циркулюючих нейтрофілів, тобто організм включає механізми неспецифічної захисної реакції. Результати наших досліджень збігаються 3 літературними даними про те, що нейтрофілія, лімфопенія i еозинопенія, яка виникає під впливом гідрокортизону і кортикостерону $\epsilon$ найбільш вираженою і постійною ознакою стресу як у поросят, так і в інших тварин (Murray and Wynn,
2011). Здатність глюкокортикоїдів проявляти регуляторний вплив на обмінні процеси в організмі тварин при їх зрушенні факторами стресу і підтримувати ці процеси на відповідному рівні лежить в основі адаптивної дії гормонів гіпофізу і надниркових залоз при стресі (Gleimer and Parham, 2003). У крові поросят Д групи через 5 діб після відлучення встановлено збільшення вдвічі кількості еозинофілів, сегментоядерних нейтрофілів на $19,7 \%(\mathrm{P}<0,01)$ і зменшення кількості лімфоцитів на 9,3\% (P < 0,01) щодо поросят К групи. Що стосується моноцитів, то вірогідних міжгрупових різниць у їх числовому значенні не спостері- 
гали. Зміни лейкограми крові поросят, яким додатково в раціон вводили добавку на основі мікроорганізмів, свідчило про підвищення імунного потенціалу та імунобіологічної реактивності їхнього організму, що зумовлено фагоцитарною активністю нейтрофілів, еозинофілів і моноцитів. 3 наведених у табл. 2 даних видно, що на 60 добу життя (через 20 діб після відлучення) у крові поросят К групи вірогідно зменшена кількість еозинофілів в 2,25 раза та лімфоцитів в 1,25 раза (P < 0,01), збільшена кількість паличко- та сегментоядерних нейтрофілів в 2,15 та 1,9 раза, моноцитів в 1,8 раза $(\mathrm{P}<0,01)$, порівняно 3 поросятами 40 добового віку (до відлучення). У крові поросят Д групи на 60 добу життя істотних змін у кількості клітинних елементів крові, порівняно з поросятами К групи виявлено не було, за винятком еозинофілів та паличкоядерних нейтрофілів: спостерігалася тенденція до їх числового збільшення. Кількість лімфоцитів перебувала у нижніх межах фізіологічної норми, кількість моноцитів і нейтрофілів не виходила за межі фізіологічної норми.

\section{Висновки}

Процес адаптації організму поросят до стресу відлучення через 5 діб супроводжується збільшенням у крові концентрації гемоглобіну в 1,35 раза $(\mathrm{P}<0,01)$, кількості лейкоцитів - в 1,21 раза $(\mathrm{P}<0,05)$ за рахунок паличко- та сегментоядерних нейтрофілів і моноцитів - у 1,54 раза ( $<<0,01)$, при зменшенні кількості еозинофілів - у 3,0 рази $(\mathrm{P}<0,001)$ і лімфоцитів - в 1,15 раза (Р < 0,01), порівняно з періодом до відлучення. Через 20 діб після відлучення у К групі тварин спостерігається зменшення у крові кількості еозинофілів у 2,25 раза та лімфоцитів - в 1,25 раза $(\mathrm{P}<0,01)$, збільшення паличко- та сегментоядерних нейтрофілів у 2,15 і 1,90 раза, моноцитів - в 1,85 раза $(\mathrm{P}<0,01)$ порівняно 3 періодом до відлучення. За використання БАКД «Праймікс-Біонорм К» через 5 діб після відлучення у крові поросят збільшується вміст гемоглобіну в 1,26 раза; через 20 діб зростає вміст гемоглобіну в 1,22 раза, кількість лейкоцитів - в 1,22 раза $(\mathrm{P}<0,01)$, нейтрофілів паличкоядерних - у 2,0 рази, сегментоядерних - в 1,37 раза $(\mathrm{P}<0,01)$ порівняно з контролем.

Перспективи подальших досліджень бачимо у досліджені стану імунологічної реактивності організму поросят у стресові періоди при включенні в раціон БАКД «Праймікс Біонорм-К».

\section{References}

Chumachenko, V.V. (2004). Klinichni ta gematologichni pokazniki v porosjat pri vidluchnomu stresi. Visnik Dnipropetrovs'kogo derzhavnogo agrarnogo universitetu. 1, 102-105 (in Ukrainian).

Gutyj, B., Leskiv, K., Shcherbatyy, A., Pritsak, V., Fedorovych, V., Fedorovych, O., Rusyn, V. \& Kolomiiets, I. (2017). The influence of Metisevit on biochemical and morphological indicators of blood of piglets under nitrate loading. Regulatory Mechanisms in Biosystems, 8(3), 427-432. doi: 10.15421/021766.

Stojanovskyj, V.G., Matsjuk, O.I., Kolotnytskyy, V.A., Kolomijets, I.A. (2016). Quantitative composition of the microflora of piglets intestinal in different periods of stress weaning under the using of additives «Bglucan» and «Biovir». Scientific Messenger LNUVMBT named after S.Z. Gzhytskyj. 18, 2(66), 176-179. doi:10.15421/nvlvet6635.

Gleimer, M. \& Parham, P. (2003). Stress Management: MHC Class I and Class I-like Molecules as Reporters of Cellular Stress. Biological Psychiatry. 19(4), 469477. doi: doi: 10.1016/S1074-7613(03)00272.

Panin, A.N. \& Malik, N.I. (2006). Probiotiki neotemlemyj komponent racionalnogo kormlenija zhivotnyh. Veterinarija, 7, 3-6 (in Russian).

O'Mahony, S.M., Marchesi, J.R., Scully, P., Codling, C., Ceolho, A.M., Quigley, E.M., Cryan, J.F. \& Dinan, T.G. (2009). Life Stress Alters Behavior, Immunity, and Microbiota in Rats: Implications for Irritable Bowel Syndrome and Psychiatric Illnesses. Biological Psychiatry. 65(3), 263-267. https:/www.ncbi.nlm.nih. gov/pubmed/18723164.

Rider, P., Voronov, E., Dinarello, C.A., Apte, R.N. \& Cohen, I. (2017). Alarmins: Feel the Stress. Journal of Immunology. 198(4), 1395-1402. doi: 10.4049/jimmunol.1601342.

Vlizlo, V.V., Fedoruk, R.S. \& Ratich, I.B. (2012). Laboratorni metody doslidzhen u biologii, tvarynnyctvi ta veterinarnij medycyni: dovidnyk (in Ukrainian).

Frick, L.R., Rapanelli, M., Bussmann, U.A., Klecha, A.J., Arcos, M.L., Genaro, A.M., \& Cremaschi, G.A. (2009). Involvement of Thyroid Hormones in the Alterations of T-Cell Immunity and Tumor Progression Induced by Chronic Stress. Biological Psychiatry. 65(11), 935-942. https://www.ncbi.nlm.nih.gov/ pubmed/19167703.

Nallagatla, S.R., Toroney, R., \& Bevilacqua, P.C. (2011). Regulation of innate immunity through RNA structure and the protein kinase PKR. Current Opinion in Structural Biology, 21(1), 119-127. doi: 10.1016/j.sbi.2010.11.003.

Kogelberg, H. \& Feizi, T. (2001). New structural insights into lectin-type proteins of the immune system. Current Opinion in Structural Biology. 11(5), 635643. doi: 10.1016/S0959-440X(00)00259-1.

Snodgrass, R.G., Huang, S., Namgaladze, D., Jandali, O., Shao, T., Sama, S., Brüne, B., \& Hwang, D.H. (2016.). Docosahexaenoic acid and palmitic acid reciprocally modulate monocyte activation in part through endoplasmic reticulum stress. The Journal of Nutritional Biochemistry. 32, 39-45. doi: 10.1016/j.jnutbio.2016.01.010.

Murray, P.J. \& Wynn, T.A. (2011). Protective and pathogenic functions of macrophage subsets. Nature Reviews Immunology. 11, 723-737. doi: $10.1038 /$ nri3073. 